\title{
Effectiveness of Brain-Based Learning for Grade Eight Students' Direct and Postponed Retention in Science
}

\author{
Khadija A. Al-Balushi \\ Dr., Senior elementary science \& mathematics supervisor, Ministry of Education, \\ Muscat, Oman, khadija.balushi@moe.om
}

Sulaiman M. Al-Balushi

Assoc. Prof., Sultan Qaboos University, Muscat, Oman, sbalushi@squ.edu.om

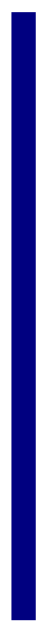

\begin{abstract}
The aim of the current study is to examine the effectiveness of brain-based learning for student direct and postponed retention in science. There were three groups in the study - one control group and two experimental groups. Brain-based learning was used in the first experimental group (mental group). In addition, technology was used in the second group as a platform to deliver brain-based learning. The control group used conventional teaching methods. There were 197 participants from grade eight. We administered a science achievement test to the three groups as a pre-test (before the beginning of the study), as a post-test (at the end of the study), and as a postponed test (six weeks after the study ended). The post-test results indicated that the technology experimental group outperformed the control group. However, the postponed test results also showed that there was no significant difference between the control group and the technology group. On the other hand, the mental experimental group performed significantly better than the other two groups on the postponed test. We suggest that the novelty effect might play a role in wavering the impact of the use of technology, however further research is needed.
\end{abstract}

Keywords: brain-based learning, cognitive processes, direct retention, hypothetical thinking, mobile education, postponed retention, science achievement

\section{INTRODUCTION}

In modern society there are rapid changes occurring in all fields, along with the emergence of various economic and educational challenges. Therefore, the possession of knowledge or skills is no longer sufficient to overcome these challenges without utilising different cognitive capabilities in various life situations (Aslan, 2015). As a result, helping individuals to achieve their highest potential has been prioritised in different educational systems. Developing mental and physical capabilities has also become one of the main objectives across disciplines. Also, brain-based learning and 
teaching approaches that are based on scientific research on how the brain learns have become the focus of much promising research. The British Royal Society acknowledges that the rapid progress of neuroscience has helped researchers understand learning in new ways (The Royal Society, 2011).

Cognitive neurology emphasises the process of acquiring knowledge, and how such a process can be explained, by understanding the nature of neural networks in the brain (Bellah et al., 2008; De Jong et al. 2009; Taylor \&Lamoreaux, 2008). Different studies have associated different brain regions with different learning tasks (Morris, 2010; Richardson, 2011; De Jong et al.; 2009, Brandoni, 2007). Research in this area has revealed that both the brain's power and the extent of its cognitive efficiency depends on the number of connections amongst neurons. Thus, the capacity of the brain to learn depends on the number of the neurons and the richness of the connectivity between them. The brain has a robust capacity to create new neuronal connections, strengthen existing ones and weaken or eliminate others (Centre for Educational Research and Innovation, 2007).Thus, connecting different elements of the topics under study together, linking present learning with previous experience and applying new learnt concepts to everyday situations encourages the formation of mental associations that broaden conceptual networks. Cardellichio and Field (1997) suggest seven brain-based thinking strategies to encourage neural branching, believing (due to their capacity to stimulate connection-making) that these strategies should be taught to students. These strategies are: 1) Hypothetical thinking, 2) Reversal, 3) Analogy, 4) Application of different symbol systems, 5) Analysis of point of view, 6) Completion, and 7) Web analysis. These techniques enhance students' divergent thinking, encouraging the creation of associations linking different parts of the subject matter, everyday life and previous experience. This association-generating process creates meaningful learning by generating new connections between different pieces of information, thus encouraging individuals to expand their thinking in new directions (Willis, 2006; Zull, 2011). In addition, this mental process of making connections enhances learners' analytical skills and maximises learning in different life situations (Pilcher, 2012). Neurologists and neuro-psychologists expect that this process of creating new associations between different concepts, experiences, information and data helps the brain to grow new connections between nerve cells through neural dendrites. The brain reacts to everyday stimuli, created by different experiences and interactions, making neuronal connections (Centre for Educational Research and Innovation, 2007).

The current study explores the effectiveness of various brain-based instructional techniques, which are designed to encourage students to form different types of associations when learning science. Technology was used as a platform to host these techniques in one of the study groups. The dependent variable of the study is 'science achievement', which is one of the main goals of school education. Much attention in different educational systems is directed towards student achievement (Hulleman, Schrager, Bodmann, \&Harackiewicz, 2010). The quality and the quantity of what the individual gains in terms of knowledge, skills and dispositions, as well as the ability to employ these learning components in different life situations, reflects the effectiveness of the educational system (Muis, Ranellucci, Franco, \& Crippen, 2013). Since learning 
gains might be easily forgotten or lost, it becomes important to focus on using teaching methods that help learners to activate their mental abilities and make meaningful associations, which make learning last longer. Therefore, the current study examines the impact of different brain-based techniques on the direct and postponed retention, and whether the use of technology helps to enhance student retention. This study contributes to the science education literature, as it is one of few studies to investigate the effectiveness of these brain-based techniques within a research design manipulating the use of technology in experimental groups. The current study could help researchers to better understand the role played by both the utilisation of brain capabilities and the making of cognitive connections in improving science learning and retention, and whether technology has a lasting impact on student learning.

\section{Brain-Based Learning Techniques}

Brain-based learning techniques have gained substantial attention and support among educational researchers. Employing a meta-analysis, Gözüyeşil and Dikici (2014) concluded that brain-based learning techniques have a positive impact on student academic achievement. Moreover, various studies have shown a positive impact of brain-based learning techniques on student performance. A study by Duman (2010) found brain-based instruction to be significantly superior in terms of student achievement compared to traditional instruction. The author used three different brainbased approaches: relaxed alertness, orchestrated immersion and active processing. Different techniques were used in each of these approaches, among which were techniques similar in principle to those we used in this study, i.e. questioning, rearrangement of content, meaningfulness, connecting, encoding and reflecting on individual experience. A similar positive impact on student academic achievement has also been observed by other researchers (Rehman, Malik, Hussain, Iqbal \& Rauf, 2012; Thomas \&Swamy, 2014).

Making connections among the elements of the subject matter related to the concepts under study is a key process in brain-based learning. Saleh (2012) found brain-based learning to be effective in enhancing secondary school students' conceptual understanding of physics and their motivation to learn the subject matter. Making connections was an essential element of the brain-based learning model used in Saleh's study. A recent study by Tafti and Kadkhodaie (2016) found that brain-based learning had a better impact on students' learning and retention than other approaches, using similar dependent variables to those examined in our study. One main technique used by these authors was to generate meanings by linking the topic under study to the lives and experience of the students. This generation of associations between different elements of knowledge, previous experience and daily life is a fundamental principle of brain-based learning. Such associations make learning more meaningful (Gözüyeşil\&Dikici, 2014). Neural research indicates that such meaningful learning and the construction of associations is made possible by the plasticity of the brain, which allows effective processing and storing of information. When learners are involved in the process of making connections between different elements of the phenomenon under study, the plasticity mechanism of the brain operates in different ways. Some synapses may be generated, while others may be eliminated (Centre for Educational Research and 
Innovation, 2007). This study addresses four brain-based learning techniques introduced by Cardellicho and Field (1997). The following sections describe these methods in detail.

\section{Hypothetical Thinking Strategy}

This strategy stimulates learners to propose hypotheses whilst thinking of a problem or situation. The strategy takes advantage of the fact that individuals face different challenges daily. Some of challenges are dealt with simultaneously, whilst others require careful thought before any action is undertaken. In both cases, the individual builds assumptions and develops different solutions based on the situation and previous experience (Elqayam et al., 2008; Leonard 2010). Thinking hypothetically is considered to be a developmental change that characterizes the development of human thinking in the adolescent stage (Centre for Educational Research and Innovation, 2007).This kind of thinking includes different high-level cognitive functions - such as predictive ability, hypothesis testing and logical reasoning - which are necessary to make decisions and choose the best solutions. The process of hypothesis generation depends on the construction of mental patterns or simulations of future possibilities or predictions. It also involves understanding the underlying patterns of reasoning and argumentation (Lawson, 2010).Another interesting feature of hypothetical thinking is that, when thinking hypothetically, the individual gives justifications for each hypothesis based on a combination of their previous experience and new information in order to reach a state of satisfaction enabling rational decisions (Jongwon, 2006; Walker, 2010). Our minds activate analytic processing whenever hypothetical thinking is involved (Stanovich, 2009). This if/then/therefore line of thinking constitutes the reproductive process of explaining and predicting in science (Lawson, 2010).

\section{Application of Symbol Systems Strategy}

Another technique to encourage neural branching and help students to generate associations among different parts of science content is to use numerical and symbolic systems rather than only using verbal symbols. The Application of Symbol Systems strategy makes this possible by encouraging learners to use symbolic and verbal systems alternatively. Students, for example, can design graphic charts or graphic relations or write equations linking the different variables under study. Willis (2007) indicates that such dual use of both expression systems helps to facilitate multiple thinking pathways in the learner's mind, and activate the long-term memory. Symbols allow ideas to be expressed in different and unique ways, which deepens student reflection. The use of visual representations is one example by which the learner becomes able to expand their comprehension of the situation under study. This happens through reflecting on and exploring different types of associations amongst the visual representations and their related text.

\section{Analysis of Point View Strategy}

This strategy encourages learners to use analytical thinking through analysing one another's points of views in terms of strengths and weaknesses. Analytical thinking helps individuals to confront problems in a systematic way, using as much information as possible to carefully organize and plan before making decisions. For better learning, Pera (2014) recommends integrating analytical activities with other tasks in the 
classroom. The National Research Council in the USA also points out that when students express their thoughts, review their knowledge and reflect on others' ideas using logical evidence, they become better able to acquire and retain learning (Duschl et. al, 2007). Park and Seung (2008) indicate that expressing points of view, whether in agreement or disagreement with others', represents one of the strategies that helps learners to think outside the box and stimulates innovative thinking. For example,this can happens through the discussion of controversial scientific issues, which often stimulate different points of view.

\section{Web Analysis Strategy}

This strategy encourages students to explore relationships between different concepts and phenomena from various angles. It helps to develop multiple alternative analyses, evaluating them separately in order to reach an accepted consensus. The Web Analysis strategy requires taking into account different internal and external (environmental) factors related to the topic of study. This strategy stems from the assumption phenomena are often associated in complex ways, but the human brain tends to simplify the links among them. However, as oppose to novices, experts concentrate on the relationships among a larger number of elements and phenomena when studying an event. In Web Analysis strategy, students can expand their knowledge of a subject by discovering nonlinear relationships between different subject elements, as well as discuss and compare them with other classmates (Rybczynski\& Hickey, 2014). Table 1 illustrates example questions which could be asked to students for each of the four brain-based teaching methods.

Table 1

Science classroom questions related to the four brain-based teaching strategies

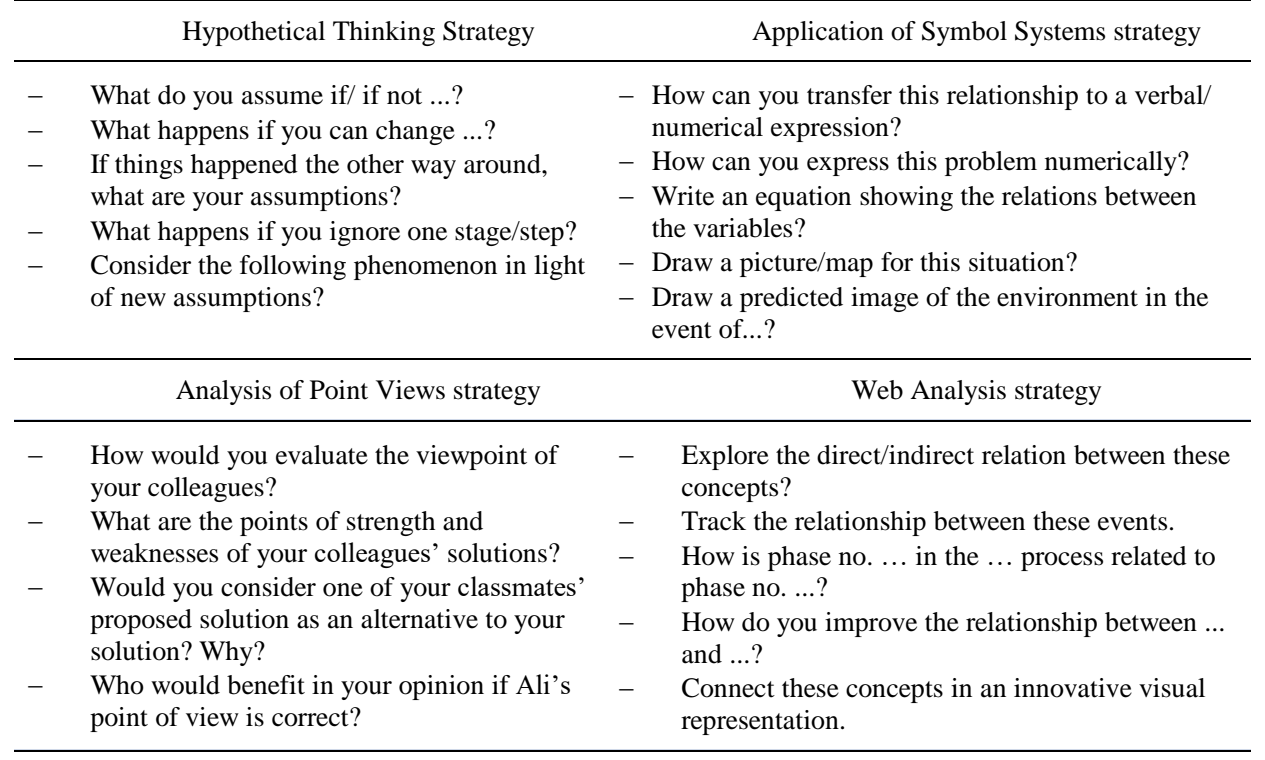




\section{METHOD}

\section{Purpose of the Study}

This study explores the impact of using different brain-based learning techniques, which are designed to encourage students to make different types of associations when learning science, on direct and postponed retention. These techniques were delivered with and without the use of technology. The main guiding questions was:

What is the effectiveness of using different brain-based learning techniques when learning science for eighth grade students' direct and postponed retention?

\section{Research Design and Procedure}

We used a quasi-experimental design. Six classes were randomly assigned to two experimental groups and a control group. The first experimental group was taught using the four brain-based learning techniques outlined by Cardellichio and Field (1997). Students in the second experimental group used Samsung® tablets and PCs whilst conducting the same brain-based learning techniques as those employed in the first experimental group. Thus, the first experimental group was called the mental experimental group and the second one was called the technological experimental group. On the other hand, the control group used the conventional teaching methods. Table 2 illustrates the design of the study.

Table 2

The design of the study

\begin{tabular}{lllll}
\hline Pre-test & Study groups & Treatment & Post-test & Postponed test \\
\hline \multirow{2}{*}{$\begin{array}{l}\text { Science } \\
\text { achievemen } \\
\text { t test }\end{array}$} & $\begin{array}{l}\text { Mental } \\
\text { experimental group }\end{array}$ & Brain-based learning techniques & & Science \\
\cline { 2 - 3 } & $\begin{array}{l}\text { Technological } \\
\text { experimental group }\end{array}$ & $\begin{array}{l}\text { Brain-based learning techniques } \\
\text { with the support technology }\end{array}$ & $\begin{array}{l}\text { Science } \\
\text { achievemen } \\
\text { achievement }\end{array}$ & $\begin{array}{l}\text { achievest } \\
\text { test }\end{array}$ \\
\cline { 2 - 3 } & control group & Conventional instruction & & \\
\hline
\end{tabular}

The study covered two science content units included in the students' eighth grade textbook. These units were the "From the Cell to the Human Body" unit and "The Heat" unit. A teacher guide was designed to assist the teachers in the experimental groups to use the brain-based learning techniques when teaching eighth grade students. Table 3 illustrates some examples of the classroom activities included in the teacher guide. The study lasted for three months and included 15 different topics, covered in 30 lessons. Each lesson was 40 minutes in duration. A science achievement test was administered three times: before the start of the treatment (pre-test), after the conclusion of the treatment (post-test), and six weeks after the second administration (postponed test).

Table 3

Examples of brain-based learning activities

\begin{tabular}{ll}
\hline \multicolumn{1}{c}{ Technique } & \multicolumn{1}{c}{ An example of activities } \\
\hline $\begin{array}{l}\text { 1. Hypothetical } \\
\text { thinking }\end{array}$ & $\begin{array}{l}\text { Imagine that the animal cell is similar to the plant cell in shape and composition, } \\
\text { what would happen? Write all consequences that you can think of. }\end{array}$ \\
\hline $\begin{array}{l}\text { 2. Web analyses } \\
\text { Think of a scheme or a system that the following organisms share: humans, plants, } \\
\text { bacteria, and viruses. Explain your answer. }\end{array}$ \\
\hline $\begin{array}{l}\text { Symbol Systems } \\
\text { brite all scientific statements you can think of by looking at this chart (a chart of } \\
\text { the temperatures recorded for a local city for a whole year). }\end{array}$ \\
\hline
\end{tabular}




\begin{tabular}{ll}
\hline $\begin{array}{l}\text { 4. Analysis of Point } \\
\text { View }\end{array}$ & $\begin{array}{l}\text { One of the cities decided to impose the use of solar energy for cooking. Study this } \\
\text { decision and explain its effects on the organisms. Then compare between your point } \\
\text { of view and the point of view of one of your classmate. }\end{array}$ \\
\hline
\end{tabular}

\section{Participants}

The study's sample consisted of 197 grade eight students from two public schools in Muscat, one male school and one female school. Three grade eight classes were selected randomly from each school and assigned randomly into the three study groups. There were 95 male students and 102 female students across the six classrooms. Table 4 illustrates the number participants in the three groups.

Table 4

Number of participates in each group

\begin{tabular}{llll}
\hline Group & School & \multicolumn{2}{c}{ Total } \\
\cline { 2 - 4 } & Female school & Male school & \\
\hline Mental group & 34 & 31 & 65 \\
\hline Technological group & 34 & 33 & 67 \\
\hline Control group & 34 & 31 & 65 \\
\hline Total & 102 & 95 & 197 \\
\hline
\end{tabular}

\section{Instrumentation}

A science achievement test was used to measure the impact of the treatments. It consisted of 30 multiple choice items from the two science units covered in the study. Each correct choice was awarded one mark, whilst incorrect responses were awarded zero. Thus, the highest possible mark for the test was 30. The test measured the following cognitive levels: knowledge, application and reasoning. The validity of the test was conducted through a panel of eleven judges; including one university science education professor, seven senior science teachers, two school science supervisors, and one measurement and evaluation expert. The panel recommended a few changes, which were added accordingly. The reliability was calculated using Cronbach Alpha, which reached (0.70).

\section{Data Analysis}

Means and standard deviations were used to report participants' performance in the three study groups. Data from the pre-test was used to check whether the three study groups were equivalent in terms of their science achievement before the start of the study. Analysis of Variance (ANOVA) was used for this purpose. All ANOVA assumptions were met. The results showed that there were significant statistical differences amongst the three study groups $(\mathrm{f}=3.08)$. Since we were interested in testing the difference between the three study groups in terms of the three cognitive levels (i.e. knowledge, application and reasoning) of the achievement test, as well as the total score, we used the Multivariate Analysis of Covariance (MANCOVA). All assumptions of MANCOVA were tested and met. We used the LSD analysis for the subsequent comparisons. Data from the post-test was used to evaluate the effectiveness of the treatment on participants' direct retention. In addition, data from the postponed administration of the achievement test were used to measure participants' postponed retention. 


\section{FINDINGS}

The main purpose of the current study was to assess the effectiveness of using different brain-based learning techniques on eighth grade students' direct and postponed retention. In terms of the three cognitive levels under study, the results of participants' performances in both the post-test and the postponed science achievement test (i.e. knowledge, application and reasoning) are illustrated in Table 5.

\section{Direct Retention}

MANCOVA analysis was performed to compare the three study groups at each cognitive level and the overall achievement of the post-test. Willis' lambda analysis for the post-test indicated there were significant statistical differences between the three groups (lambda $=0.91 ; \mathrm{f}=2.27$ ). MANCOVA analysis indicated that there were statistical significant differences in the application level $(\mathrm{f}=3.86)$ and the overall performance of participants in the post-test $(\mathrm{f}=4.25)$. The ad-hoc LSD analysis reveals that the only significant differences were between the technological and control groups in both the application level and the overall performance in the post-test (in favour of the technological group).

\section{Postponed Retention}

Willis' lambda analysis for the postponed test detected statistically significant differences (lambda $=0.91 ; \mathrm{f}=2.32$ ). MANCOVA analysis indicated that there were statistically significant differences between the three study groups in the three cognitive levels: Knowledge $(\mathrm{f}=2.98)$, application level $(\mathrm{f}=4.81)$ and reasoning $(\mathrm{f}=4.81)$. In addition, there were significant differences in the overall performance of participants in the postponed test $(\mathrm{f}=4.13)$. The ad-hoc LSD analysis indicates that there were significant differences between the mental and control groups in the knowledge level, reasoning level and the overall performance in the postponed test (in favour of the mental group). In addition, the mental group outperformed the technological group in the reasoning level. No other significant differences could be observed.

Table 5

Means and standard deviations for the performance of participants in the post and postponed science achievement test

\begin{tabular}{|c|c|c|c|c|c|c|c|}
\hline \multirow[t]{2}{*}{ Cognitive Level } & \multirow[t]{2}{*}{ Treatment } & \multirow[t]{2}{*}{$\mathrm{N}$} & \multirow[t]{2}{*}{$\max$ score } & \multicolumn{2}{|r|}{ Post } & \multicolumn{2}{|c|}{ Postponed } \\
\hline & & & & $\mathrm{M}$ & SD & $M$ & SD \\
\hline \multirow{3}{*}{ Knowledge } & Mental & 65 & 10 & 5.80 & 1.94 & 5.95 & 2.38 \\
\hline & Technological & 67 & 10 & 5.67 & 1.89 & 5.26 & 2.72 \\
\hline & control & 65 & 10 & 5.66 & 1.95 & 5.02 & 2.24 \\
\hline \multirow[t]{3}{*}{ Application } & Mental & 65 & 15 & 7.87 & 2.84 & 7.08 & 2.95 \\
\hline & Technological & 67 & 15 & 8.54 & 2.87 & 6.69 & 2.74 \\
\hline & control & 65 & 15 & 7.43 & 3.06 & 6.70 & 3.48 \\
\hline \multirow[t]{3}{*}{ Reasoning } & Mental & 65 & 5 & 2.60 & 1.27 & 2.75 & 1.29 \\
\hline & Technological & 67 & 5 & 2.77 & 1.33 & 2.12 & 1.23 \\
\hline & control & 65 & 5 & 2.78 & 1.80 & 2.34 & 1.47 \\
\hline \multirow{3}{*}{$\begin{array}{l}\text { Overall } \\
\text { Achievement }\end{array}$} & Mental & 65 & 30 & 16.13 & 4.69 & 15.67 & 5.52 \\
\hline & Technological & 67 & 30 & 16.90 & 4.50 & 14.31 & 5.08 \\
\hline & control & 65 & 30 & 15.26 & 4.53 & 13.57 & 6.23 \\
\hline
\end{tabular}




\section{DISCUSSION AND CONCLUSION}

The current study investigated the impact of different brain-based learning techniques on eighth grade students' direct and postponed retention. There were three study groups: mental, technological and control. The direct measurement of participants' achievement after the conclusion of the study revealed that there was an advantage held by the technological group compared to the control group. However, the follow-up measurement of participants' retention, six weeks after the conclusion of the study, indicated an advantage held by the mental group over the control group in the knowledge level, reasoning level and the overall performance. Furthermore, there was also a significant advantage held by the mental group over the technological group in the reasoning level of the achievement test. These findings might first indicate that the brain-based learning techniques had a more lasting impact on student retention than the conventional teaching techniques. Second, these findings might also indicate that the use of technology had a short-term positive impact on participants' performance.

Each of the three study groups had its own features, contributing to the study findings. Students in the mental group interacted with different classroom activities related to four brain-based techniques. Some of the activities were done individually, while others were done in small groups. Each of these activities provided opportunities for students to construct their own hypotheses, ideas and alternative solutions in different situations, verify the validity of the information provided, analyse the information and consider how different pieces of information are related. We believe that these mental activities of analysis and making connections enhanced the ability of the students in the mental group to understand the concepts and retain the scientific information better than the students in the control group, who had fewer opportunities to analyse the information provided and develop meaningful connections. In addition to these mental activities, students in the technological group had the opportunity to use the XMind software to design different maps that made connections between different concepts. We believe these design activities resulted in the superiority of the technological group in the posttest. In contrast, while control group students participated in different classroom discussions and worked in small groups to conduct some classroom activities, these discussions and activities did not follow a systematic sequence in analysing the material or creating connections between different elements as in the brain-based learning techniques used in the two experimental groups.

The positive impact of different thinking strategies taught to students in the current study on direct and postponed retention reflects that participants interacted positively with the introduced strategies. Literatures show that when instructional methods focus on enhancing cognitive processes related to achievement, student performance is positively impacted (Gambari et al., 2014; Esq, 2015; Tajudin\&Chinnappan, 2016). The four strategies taught in the current study emphasise high-level cognitive processes. These processes coincide with the cognitive dimensions that the achievement test emphasised. For instance, the hypothetical thinking strategy encourages the ability to predict, test hypotheses and think logically. These cognitive processes are thinking processes essential to the cognitive dimensionsof application and reasoning, which were 
components assessed by the achievement test. These cognitive processes also ignited student curiosity - an essential element of success in science achievement (Tatar, Tüysüz, Tosun\&İlhan, 2016). Also, hypothetical thinking encourages two important science processes: explanation and prediction (Lawson, 2010).

Furthermore, when students use the analysis of points of view strategy, they practice analytical thinking. The web analysis strategy encourages students to build associations and the application of symbol systems strategy encourages them to translate from verbal expressions to symbolic representations. These two mental processes are necessary to both the analytical and reasoning cognitive domains. The performance advantage of the experimental groups (one at post-test, one at follow-up) stemmed, arguably, from the improvements students made in their analysis and reasoning skills. Although the conventional teaching methods in the control group covered different tasks related to the analysis and reasoning levels, they were not given enough emphasis, as the knowledge level is the main focus of conventional teaching methods.

The better performance of the technological group compared to the control group in the post-test could be explained by the advantages that educational technologies provide, enhancing the learning environment. The use of technology in different research studies has been demonstrated as superior to conventional teaching methods (Ceresia, 2016; Muslem\& Abbas, 2017) and to lead to meaningful learning and effective classroom engagement (Önal, 2017). The positive impact of technology-based instruction on student learning has been observed in different studies (e.g. Gambari et al., 2014; Esq, 2015; Orhan\&Kadir, 2014; Walker, 2010). Learning technologies encourage flexible thinking, develop communication skills and enhance re-conceptualization (Barak \&Levenberg, 2016). Likewise, learning technologies support learning environments and make it easier for students to propose their own inquiry focus, produce their own data, and continue their inquiry as new questions arise (Kim, 2016). Technology also helps to shift the focus of science instruction from the direct memorising of scientific facts to engaging in developing rich, productive and applicable knowledge (Gerard, Matuk\& Linn 2016). All or some of these features of learning technologies may have interacted with the brain-based learning techniques used in the technological experimental group and played a role in the superior performance of this group in the post-test (compared to the control group).

\section{LIMITATIONS AND RECOMMENDATIONS}

The findings of the current study could help science education researchers better understand the role of technology in supporting brain-based learning techniques in particular, and other teaching methods in general. Some researchers have cautioned that the impact of technology might be due to the novelty effect which occurs when participants' enthusiasm and engagement increases because they are doing something different or new (Ayyildiza\&Tarhan, 2013; Keller et al., 2005; Kirika\&Boz, 2012). This novelty effect was also noticed when the impact of animations on students' understanding of organic chemistry was studied (Al-Balushi\& Al-Hajri, 2014). Similarly, in the current study we noticed that students in the technological group were excited to use the tablets and interact with the X-mind program. In a follow-up interview 
after the conclusion of the study, a high level of excitement was evident. For instance a male student of the technology group mentioned, "you do not feel the time when we study science using these methods." A female student from the technology group also emphasised that "this could not be the last lesson in the day. You feel that this is one of the morning lessons. This is because we enjoy these activities so much." Thus, the shortterm effect of the use of technology in the current study might support the remark about the novelty effect of the use of technology. However, further research is needed to verify: 1) The nature of this novelty effect, 2) Whether the short-term effect is due to this effect, and 3) Whether the use of technology in teaching distracts students from the benefits of other instructional activities.

The mental experimental group of the current study indicated a longer lasting impact, as it outperformed the control group in the postponed test. This main finding of the current study leads us to recommend that science teachers be trained to teach students the brainbased learning techniques adopted by the current study. In addition, these recommended teaching methods could be integrated in science textbooks, helping students to make more connections with different aspects of the scientific concepts under study and to construct more associations with their everyday experiences. Furthermore, the shortterm impact of the use of technology, as a main result of the current study, could be an interesting topic of further research. Different types of learning technologies could be compared in terms of their long-term impact on science achievement.

\section{ACKNOWLEDGMENT}

The authors would like to express their sincere appreciation to Ms. Rola and Mr. Mohammed Al Balushi for their cooperation and motivation whilst implementing the study.

\section{REFERENCES}

Al-Balushi S.M., \& Al-Hajri, S. (2014). Associating animations with concrete models to enhance students' comprehension of different visual representations in organic chemistry. Chemistry Education Research \& Practice, 15, 47-58.

Aslan, S. (2015). Is learning by teaching effective in gaining 21 st century skills? The views of pre-service science teachers. Educational Sciences: Theory \& Practice, 15(6), 1441-1457.

Ayyıldıza Y. \&Tarhan L. (2013). Case study applications in chemistry lesson: gases, liquids, and solids. Chemistry Education Research \& Practice, 14(4), 408-420.doi: $10.1039 / \mathrm{c} 3 \mathrm{rp} 20152 \mathrm{j}$.

Barak, M., \&Levenberg, A. (2016). Flexible thinking in learning: An individual differences measure for learning in technology-enhanced environments. Computers \& Education, 99, 39-52.

Bellah, K.A., Robinson, J.S., Kaufman, E.K., Akers, C., Haase-Wittler, P., \& Martindale, L. (2008). Brain-based learning: A synthesis of research. NACTA Journal, 52(2), 15. 
Brandoni, C. R. (2007). Merging divergent thinking with neuropsychology: Implications for research and practice in science education. Unpublished doctorate dissertation, Columbia University, Manhattan, New York, USA.

Cardellichio,T. \& Field, W. (1997). Seven strategies that encourage neural branching. Educational Leadership, 54, 33-36.

Centre for Educational Research and Innovation (2007). Understanding the brain: The birth of a learning science. Danvers, MA, USA: OCED.

Ceresia, F. (2016). Interactive learning environments (ILEs) as effective tools for teaching social sciences, Procedia - Social and Behavioural Sciences, 217, 512-521.

De Jong, T., van Gog, T., Jenks, K., Manlove, S., van Hell, J., \&Jolles, J. (2009). Explorations in learning and the brain. Dordrecht: Springer.

Duman, B. (2010). The effects of brain-based learning on the academic achievement of students with different learning styles.Educational Sciences: Theory \& Practice, 10(4), 2077-2103.

Duschl, R.A., Schweingruber, H.A., \&Shouse, A.W. (Eds.). (2007). Taking science to school: Learning and teaching science in grades $K-8$. Washington, DC: National Academies Press.

Elqayam S., Handley S., Evans J., Bacon A. (2008). On some limits of hypothetical thinking. The Quarterly Journal of Experimental Psychology, 61(5), 784-808.

Esq, E. (2015). Enhancing academic achievement and retention in senior secondary school chemistry through discussion and lecture methods: A case study of some selected secondary schools in Gboko, Benue State, Nigeria. Journal of Education and Practice, 6(21), 155-161.

Gözüyeşil, E.\&Dikici, A. (2014). The effect of brain based learning on academic achievement: A meta-analytical study. Educational Sciences: Theory \& Practice, 14(2), 642-648. doi: 10.12738/estp.2014.2.2103.

Gambari A., Yaki A., Gana E., Ughovwa E. (2014) Improving secondary school students' achievement and retention in biology through video-based multimedia instruction. InSight: A Journal of Scholarly Teaching, 9, 78-91.

Gerard L., Matuk, C. \& Linn, M. (2016). Technology as inquiry teaching partner. Journal of Science Teacher Education, 27, 1-9. doi: 10.1007/s10972-016-9457-4.

Hulleman, C.S., Schrager, S.M., Bodmann, S.M. \&Harackiewicz, J.M. (2010). A metaanalytic review of achievement goal measures: Different labels for the same constructs or different constructs with similar labels? Psychological Bulletin, 136, 422-449.

Jongwon Park (2006). Modelling analysis of students' processes of generating scientific explanatory hypotheses. International Journal of Science Education, 28(5), 469-489. doi:10.1080/09500690500404540. 
Keller J., Deimann M. \& Liu Z., (2005, October). Effects of integrated motivational and volitional tactics on study habits, attitudes, and performance. Paper presented at The annual meeting of the association for educational communications and technology, Orlando, Florida.

Kim, H. (2016). Inquiry-based science and technology enrichment program for middle school-aged female students. Journal of Science Education Technology 25, 174-186.

Kirıka, O., \&Boz Y., (2012). Cooperative learning instruction for conceptual change in the concepts of chemical kinetics, Chemistry Education Research \& Practice, 13, 221236.

Lawson, A. (2010). Basic inferences of scientificreasoning, argumentation, anddiscovery. Science Education, 94, 336-364. doi: 10.1002/sce.20357.

Leonard N. (2010). The relationship between hypothetical thinking and cognitive biases. $\quad$ Retrieved 5 August 2014 from: http://www.unc.edu/courses/2010spring/psyc/433/001/tutorials/leonard.html

Morris, L. T. (2010). Brain-based learning and classroom practice: A study investigating instructional methodologies of urban school teachers. Unpublished doctorate dissertation, Arkansas State University, Jonesboro, Arkansas, USA.

Muis K., Ranellucci J., Franco G., \&Crippen K. (2013). The interactive effects of personal achievement goals and performance feedback in an undergraduate science class. The Journal of Experimental Education, 81(4), 556-578.

Muslem, A. \& Abbas, M. (2017). The effectiveness of immersive multimedia learning with peer support on English speaking and reading aloud. International Journal of Instruction, 10(1), 203-218. doi:10.12973/iji.2017.10113a.

Önal, N. (2017). Use of interactive whiteboard in the mathematics classroomStudents' perceptions within the framework of the technology acceptance model. International Journal of Instruction, 10(1), 67-86. doi:10.12973/iji.2017.1045a.

Orhan E.; Kadir B. (2014). Effect of web assisted education supported by six thinking hats on students' academic achievement in science and technology classes. European Journal of Educational Research, 3(1), 9-23.

Park, S., \&Seung, E. (2008). Creativity in the science classroom: Four strategies to help students think outside the box. The Science Teacher, 75(6), 45.

Pera, A. (2014). Neural machanism underlying school based learning. Contemporary Readings in Law and Social Justice, 6(1), 7-12.

Pilcher, J. (2012). Growing dendrites and brain-based learning. Neonatal Network, 31(3), 191-4.

Rehman,A., Malik, M., Hussain, S., Iqbal, Z.\& Rauf, M. (2012). Effectiveness of brainbased learning theory on secondary level students of urban areas. Journal of Managerial Sciences, 6(1), 113-122. 
Richardson, J. (2011). Increasing left and right brain communication to improve learning for tenth grade students in a public school. Unpublished doctorate dissertation, Walden University, Minneapolis, Minnesota, USA.

Rybczynski, S., Li, Z., \& Hickey, R.J. (2014). Next generation botany. The Science Teacher, 81(7), 53.

Saleh, S. (2012). The effectiveness of brain-based teaching approach in dealing with the problems of students' conceptual understanding and learning motivation towards physics. Educational Studies, 38(1), 19-29, doi: 10.1080/03055698.2011.570004.

Stanovich, K. E. (2009). Distinguishing the reflective, algorithmic, and autonomous minds: Is it time for a tri-process theory? In J. Evans \& K. Frankish (Eds.) In two minds: Dual processes and beyond (pp. 55-88). Oxford, England: Oxford University Press.

Tajudin, N. \&Chinnappan, M. (2016). The link between higher order thinking skills, representation and concepts in enhancing TIMSS tasks. International Journal of Instruction, 9(2), 199-214. doi:10.12973/iji.2016.9214a.

Tafti, M. \&Kadkhodaie, M. (2016). The effects of brain-based training on the learning and retention of life skills in adolescents. International Journal of Behavioural Science, 10(4): 140-144.

Tatar, E., Tüysüz, C., Tosun, C. \&İlhan, N. (2016). Investigation of factors affecting students' science achievement according to student science teachers. International Journal of Instruction, 9(2), 153-166. doi:10.12973/iji.2016.9211a.

Taylor, K, \&Lamoreaux, A. (2008). Teaching with the brain in mind. New Directions for Adult and Continuing Education, 49-59. doi:10.1002/ace.305

Thomas, M. \&Swamy, S. (2014). Brain based teaching approach - a new paradigm of teaching. International Journal of Education and Psychological Research, 3(2), 62-65.

The Royal Society (2011). Brain waves module 2: Neuroscience: Implications for education and lifelong learning. Retrieved 11 may 2014 from https://royalsociety.org/ /media/Royal_Society_Content/policy/publications/2011/4294 975733.pdf.

Walker, J. J. (2010). Minesweeper and hypothetical thinking action research \& pilot study. Retrieved at 14 June 2015 from the World Wide Web: http://search.proquest.com/docview/742867762 ? accountid $=27575$

Willis, J. (2006). Research-based strategies to ignite student learning. [Electronic resource]: insights from a neurologist and classroom teacher. Alexandria, VA: Association for Supervision and Curriculum Development (ASCD).

Willis, J. (2007). Brain-based teaching strategies for improving students' memory, learning, and test-taking success. Childhood Education, 83(5), 310-315.

Zull, J. E. (2011). From brain to mind: Using neuroscience to guide change in education. Sterling: Stylus Publishing. 